\title{
3-D VISUALIZATION: VOLCANIC HAZARD MAPS EDUCATE PEOPLE EXPOSED TO VOLCANIC RISK
}

\author{
Henry Villegas, Lider Grupo de Percepción Remota, INGEOMINAS, División de \\ Reconocimientos Geo-Científicos, Diagonal 53 No. 34-53, Bogotá D.C., Colombia. E-mail: \\ henville@ingeomin.gov.co, villegashenry@hotmail.com
}

\begin{abstract}
Since the most reliable volcanic hazard map will be of little use unless it is presented in a meaningful format, the Volcanic Hazard Map of Nevado del Huila Volcano (Colombia) was combined with remote sensing data and visualized in 3-D. This visualization methodology could be used with any volcanic hazard map available, in order to generate products that could help improving the communication between volcanologists and people not familiar with volcanoes. The right understanding of any volcanic hazardous situation will avoid or minimize damaging consequences to people exposed to such natural risk.
\end{abstract}

Keywords: GIS, Landsat TM, Nevado del Huila Volcano, remote sensing, volcanic hazard, volcanic hazard map, 3-D visualization.

Resumen: Dado que hasta el mapa de amenaza volcánica más confiable será de poca utilidad a menos que se presente en un formato significativo, el Mapa de Amenaza Volcánica del Volcán Nevado del Huila (Colombia), se combinó con datos de percepción remota y fue visualizado en tres dimensiones. Esta metodología de visualización puede aplicarse a cualquier mapa de amenaza volcánica disponible, para generar productos que ayuden a mejorar la comunicación entre los vulcanólogos y gente no familiarizada con los volcanes. La comprensión correcta de cualquier situación de amenaza volcánica, evitará o minimizará sus consecuencias letales sobre la gente expuesta a este tipo de riesgo natural.

Palabras clave: Landsat TM, Volcán Nevado del Huila, percepción remota, amenaza volcánica, mapa de amenaza volcánica, visualización en tres dimensiones. 


\section{Introduction}

Volcanic eruptions in remote, sparsely populated regions rarely cause human or socioeconomic impact, but hazardous processes associated with eruptions in or near inhabited areas produce serious problems. Recently, the population at risk from volcano hazards increased to at least 500 million, a number comparable to the estimated world population at the beginning of the 17th century (Tilling \& Lipman, 1993). Population growth demands that people continue to live in and expand into high-hazard areas, many of which are of considerable agricultural and economic value. As a result, damage from natural catastrophes will continue to rise (Voight, 1990).

\section{The Colombian Andean Highlands}

In Colombia, near the Ecuadorian frontier, the Andes mountains divide into three distinct, roughly parallel chains, called cordilleras, that extend northeastward almost to the Caribbean Sea (Fig. 1). Altitudes reach more than 5,700m, and mountain peaks are permanently covered with snow. The elevated basins and plateaus of these ranges have a moderate climate that provides pleasant living conditions and in many places enables farmers to harvest twice a year.

The Cordillera Occidental in the west, the Cordillera Central in the center, and the Cordillera Oriental in the east have different characteristics (Fig. 1). The Cordillera Occidental is relatively low and is the least populated of the three cordilleras. Summits are only about $3,000 \mathrm{~m}$ above sea level and do not have permanent snows. The relatively low elevation of the cordillera allows dense vegetation, which on its western slopes is truly tropical.

The Cordillera Central is the loftiest of the mountain systems. Its crystalline rocks form an $800 \mathrm{Km}$ long towering wall dotted with snow covered volcanoes. There are no plateaus in this range and no passes under $3,300 \mathrm{~m}$. The highest peak in this range, an active volcano called Nevado del Huila (Fig. 1), reaches 5,439m above sea level, has active hydrothermal areas near its summit and is covered with glaciers above an elevation of about $4,400 \mathrm{~m}$. The second highest peak is another snow covered active volcano, Nevado del Ruiz 


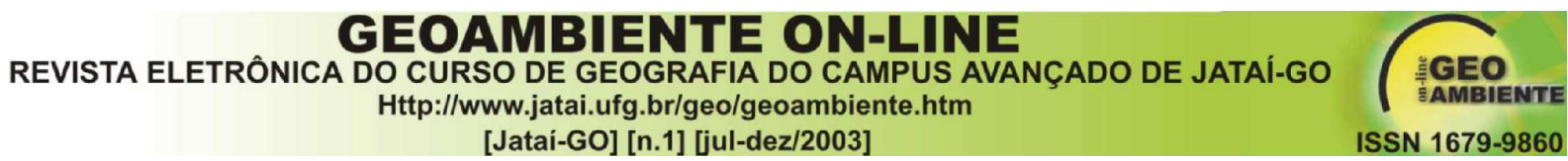

(Fig. 1), which erupted violently on November 13, 1985. Toward its northern end, this cordillera separates into several branches that descend toward the Caribbean Coast (Fig. 1).

In the Cordillera Oriental at elevations between 2,500 and $2.700 \mathrm{~m}$, three large fertile basins and a number of small ones provide suitable areas for settlement and intensive economic production.

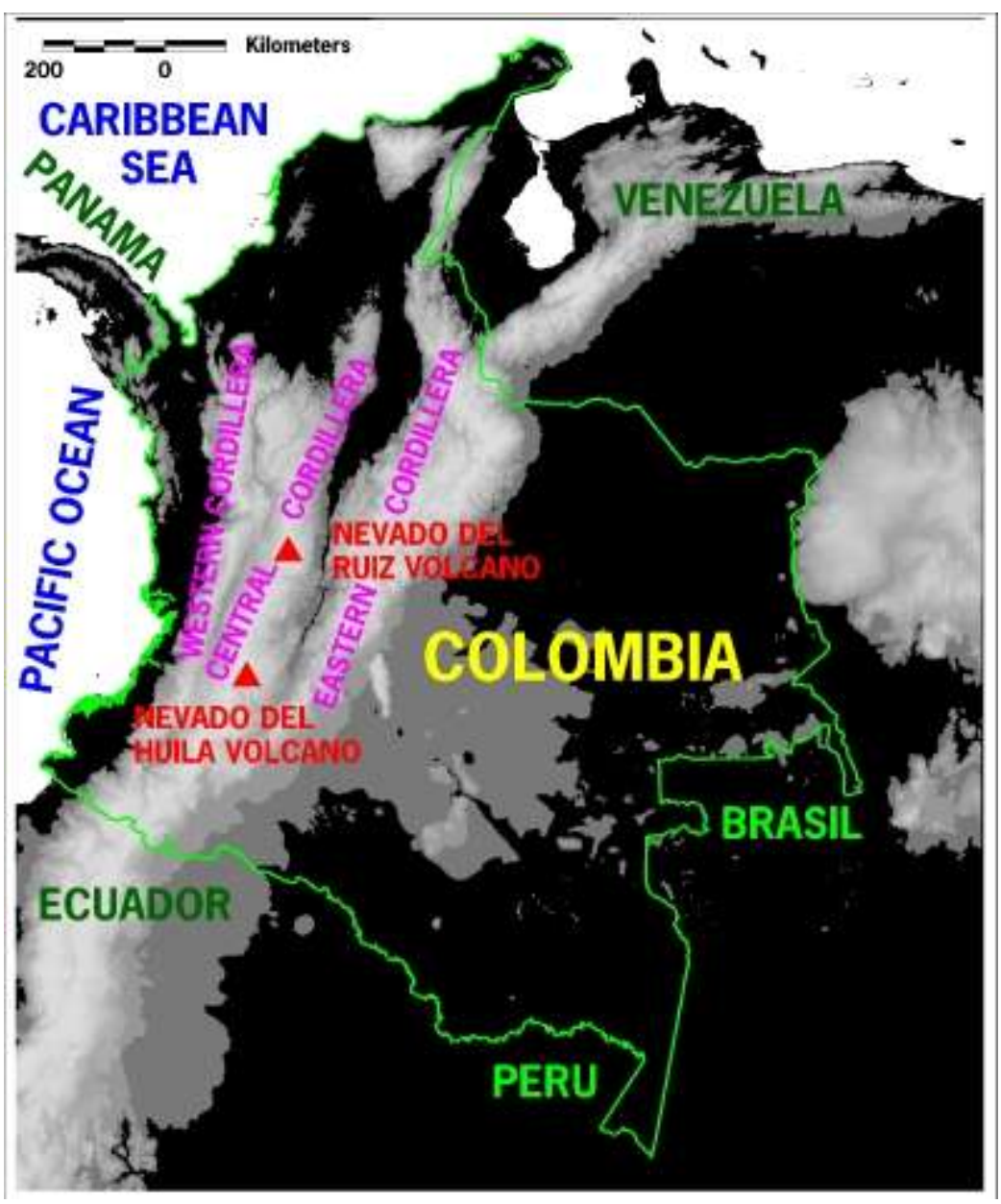

Fig. 1. Digital Elevation model of Colombia that shows the physiography and geographic location of Nevado del Huila and Nevado del Ruiz volcanoes. The dark tones correspond with low heights while the light ones correspond with high heights. 


\section{GEOAMBIENTE ON-LINE \\ REVISTA ELETRÔNICA DO CURSO DE GEOGRAFIA DO CAMPUS AVANÇADO DE JATAÍ-GO \\ Http://www.jatai.ufg.br/geo/geoambiente.htm \\ [Jatai-GO] [n.1] [jul-dez/2003]

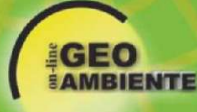

Fig. 1. Modelo de elevación digital de Colombia que muestra la localización geográfica y la fisiografía de los volcanes Nevado del Huila y Nevado del Ruiz. Los tonos oscuros corresponden con las alturas menores y los claros con las mayores.

\section{Volcanic Hazard in Colombia}

Volcanoes with their eruptions and other related hazards had long been regarded in Colombia (South America) as exotic phenomena found only in remote corners of the world. In 1985 when Nevado del Ruiz Volcano (Fig. 2) demonstrated a wide spectrum of nature's fury that perception changed dramatically. Its Nov. 13, 1985, volcanic eruption was the worst of the decade. When a complex sequence of hot, dry rock debris masses moving like a fluid erupted, the hot masses interacted with snow and ice on the volcano's ice cap, triggering masses of water-saturated rock debris (lahars) that moved down the volcano slopes like wet concrete (Pierson et al, 1990).
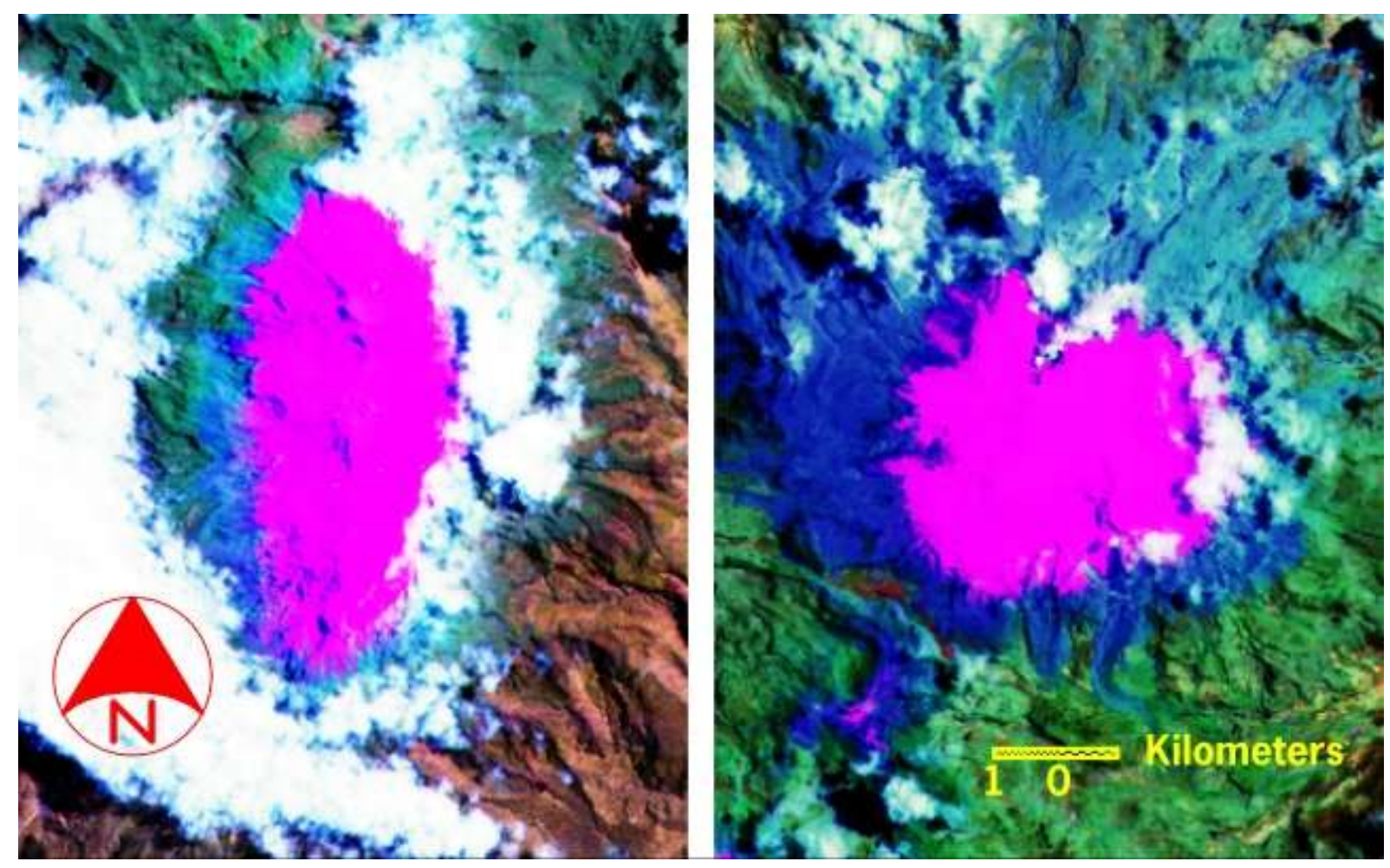
Figure 2. These Landsat TM 5 images (4R-5G-2B) compare Nevado del Huila Volcano (left) with Nevado del Ruiz Volcano (right). Snow and ice are in magenta, clouds in white and primary vegetation in green and brown.

Figura 2. Estas imágenes Landsat TM 5 (4R-5V-2 A) comparan el Volcán Nevado del Huila (izquierda) con el Volcán Nevado del Ruiz (derecha). La nieve y el hielo se muestran en magenta, las nubes en blanco, y la vegetación primaria en verde y marrón.

With these lahars ranked as the deadliest in recorded history, the Ruiz eruption was the second worst volcanic disaster of the $20^{\text {th }}$ century, its death toll of 23,000 fatalities ranks fourth in history. The town of Armero was virtually obliterated and $75 \%$ of its inhabitants perished (Voight, 1990). This catastrophic event of nature as well as the September 1985 Coast of Mexico earthquake, which killed about 30000 people in Mexico City, catalized the declaration of the 1990`s as the International Decade for Natural Disaster Reduction.

Immediately after this disaster happened, inhabitants of areas within active volcanoes influence zones, felt threatened by possible volcanic catastrophes as severe as the Nevado del Ruiz one. That was the case of the people who lives in the surroundings of Nevado del Huila Volcano (Fig. 2), whom reported explosions and volcanic eruptions at its active cone the same day and time that the lethal Ruiz Volcano eruption happened. Such reports made think about the possible connection of the two volcanic phenomena, but everything seems to indicate that the explosion reported there was the Nevado del Ruiz Volcano itself, which was equally felt in other colombian provinces far away from its influence zone.

\section{The 6 June 1994 Paez Earthquake}

At 15:47 hrs on 6 June 1994, an earthquake triggered by movement along a fault, shook the Paez River Valley, south Nevado del Huila Volcano. During the earthquake, several villages in the Valley of this river were destroyed, some by earthquake shaking, some by landslides (including debris flows), and some by both. The earthquake and resulting landslides and debris flows (water-saturated flows with plastic properties that deposit sediment en 
masse), resulted in 271 reported deaths; 158 people were injured and about 1700 are missing (Martinez et al, 1995).

Nevado del Huila Volcano had no direct relation to the earthquake. Although its epicenter was located only $10 \mathrm{Km}$ from its crest (Fig. 3), the quake does not appear to have had a significant effect on the glaciers that characterize it. There was no indication that the glaciers or their snowpacks contributed any ice or water to the landslides and debris flows.

These flows formed mainly in the epicentral area, in the Paez River basin at an elevation of about $3,000 \mathrm{~m}$. The largest flows followed this river and its largest tributaries, traveling as far as the Magdalena River and Betania Reservoir (Fig. 3), some $120 \mathrm{Km}$ downstream. In the upper $35 \mathrm{Km}$, they destroyed villages that were located near the rivers, mostly at elevations of 500-1500 m. In the downstream $85 \mathrm{Km}$, they destroyed bridges and roads before dumping into Betania Reservoir at an elevation of about $500 \mathrm{~m}$ (Martinez et al, 1995). 

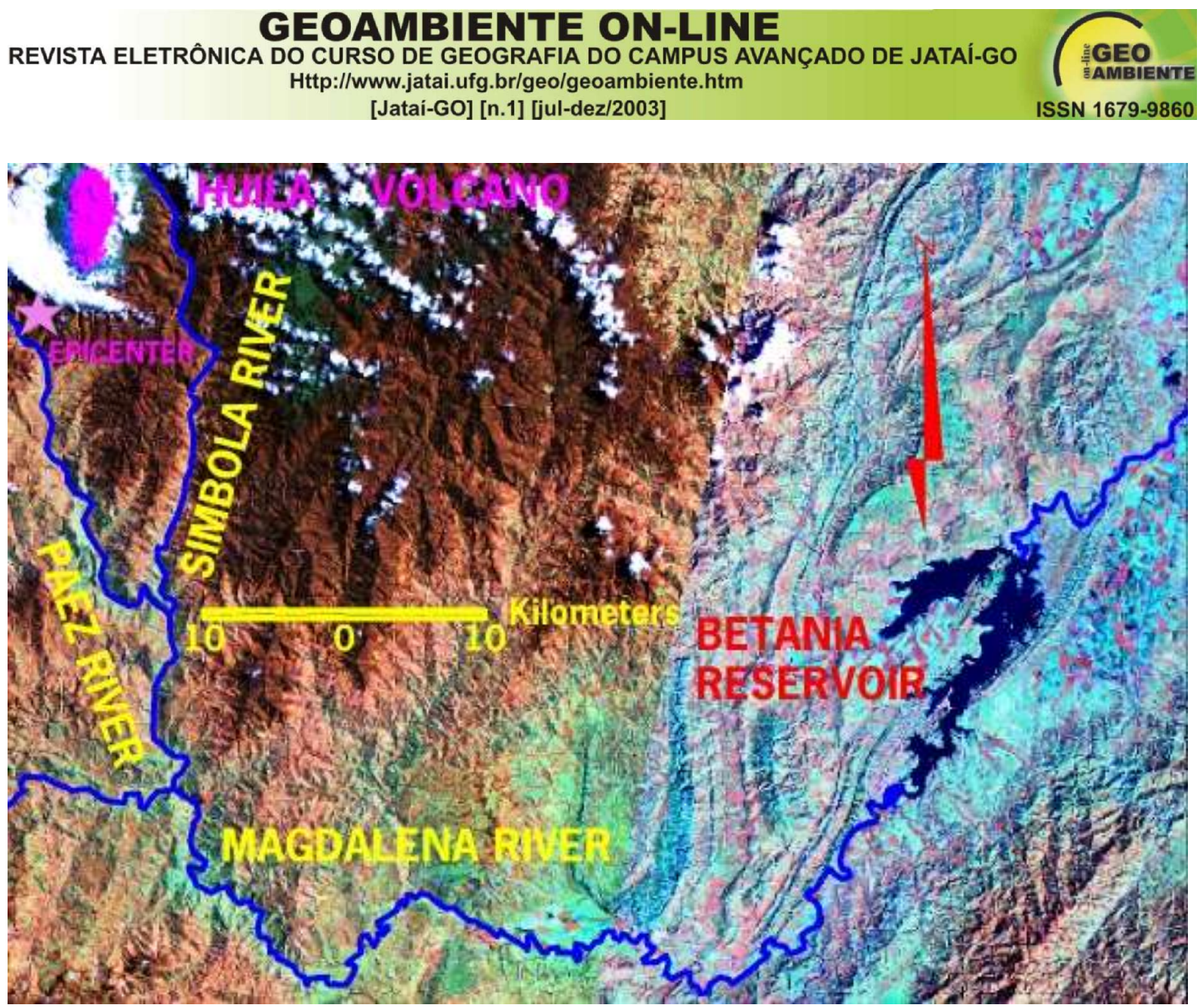

Figure 3. This Landsat TM 5 mosaic (4R-5G-2B) shows the Nevado del Huila Volcano influence zone, which reaches up to Betania Reservoir.

Figura 3. Este mosaico Landsat TM 5 (4R-5V-2 A) muestra la zona de influencia del Volcán Nevado del Huila, que llega hasta la Represa de Betania.

In Nevado del Huila Volcano influence zone, earthquakes could be equally triggered by volcanic eruptions. If earthquake shaking is strong enough, it can have effects on the volcano's glaciers, which could contribute ice or water to the succeeding landslides and debris flows, making them bigger and stronger. If these succeeding phenomena form dams in the main rivers, they certainly will be more dangerous. 


\section{GEOAMBIENTE ON-LINE}

\section{Emergency Planning}

Volcanic hazard-zone maps are perhaps the most easily understandable information that public officials and ordinary citizens can use in planning for volcanic emergencies. The most common means by which a volcano's history and potential for future activity can be presented is a map outlining areas of risk from a particular kind of volcanic or hydrologic hazard. The hazard zones must outline an area likely to be affected by a given kind of event and should also give some idea of the recurrence interval for that event (Wright \& Pierson, 1992). Government authorities must evaluate these maps, along with socio-economic and political factors, in the development of long-range land-use plans, and to design along with civil authorities, emergency evacuation paths for the surrounding townships. In fact, an alert issued immediately after the onset of any eruption, could provide enough time for the people to escape, if they are informed and prepared in advance.

Since it is not well known how snow and ice are melted by volcanic material to form lahars (Wright \& Pierson, 1992), ice capped volcanoes like Nevado del Ruiz and Nevado del Huila must be considered very dangerous (Fig. 2). Nevado del Huila Hazard Map has three hazard zones around its crater (Fig. 4 A), classified into high (red colored), medium (orange) and low (yellow) (INGEOMINAS, 2000). The high hazard zone corresponds to an area where volcanic events of high severity will take place. In this zone there will be no survivors and property will also be destroyed. The medium hazard is a transition zone that corresponds to an area that could be affected by the same volcanic phenomena as the high hazard zone, but for larger eruptions. The low hazard zone is the smallest area. Although the severity is lowest for people and property in this zone, it should be considered when planning any type of construction.

\section{Communication Problems}

Outreach measures to ensure public safety from volcanic eruptions begin long before an emergency develops, especially with volcanic hazard assessments and public education, and continue through periods of volcanic unrest and eruptions with forecasts, predictions, and real-time tracking of eruptive activity (Wright \& Pierson, 1992). Decisions regarding access 


\section{GEOAMBIENTE ON-LINE \\ REVISTA ELETRÔNICA DO CURSO DE GEOGRAFIA DO CAMPUS AVANÇADO DE JATAÍ-GO \\ Http://www.jatai.ufg.br/geo/geoambiente.htm \\ [Jatai-GO] [n.1] [jul-dez/2003]

and evacuation usually rest with local government officials, emergency managers or civil defense personnel. These decisions carry enormous social and economic costs and often are resisted by the local community. Unfortunately, communication between scientists, who predict disaster and pragmatic decision makers is difficult.

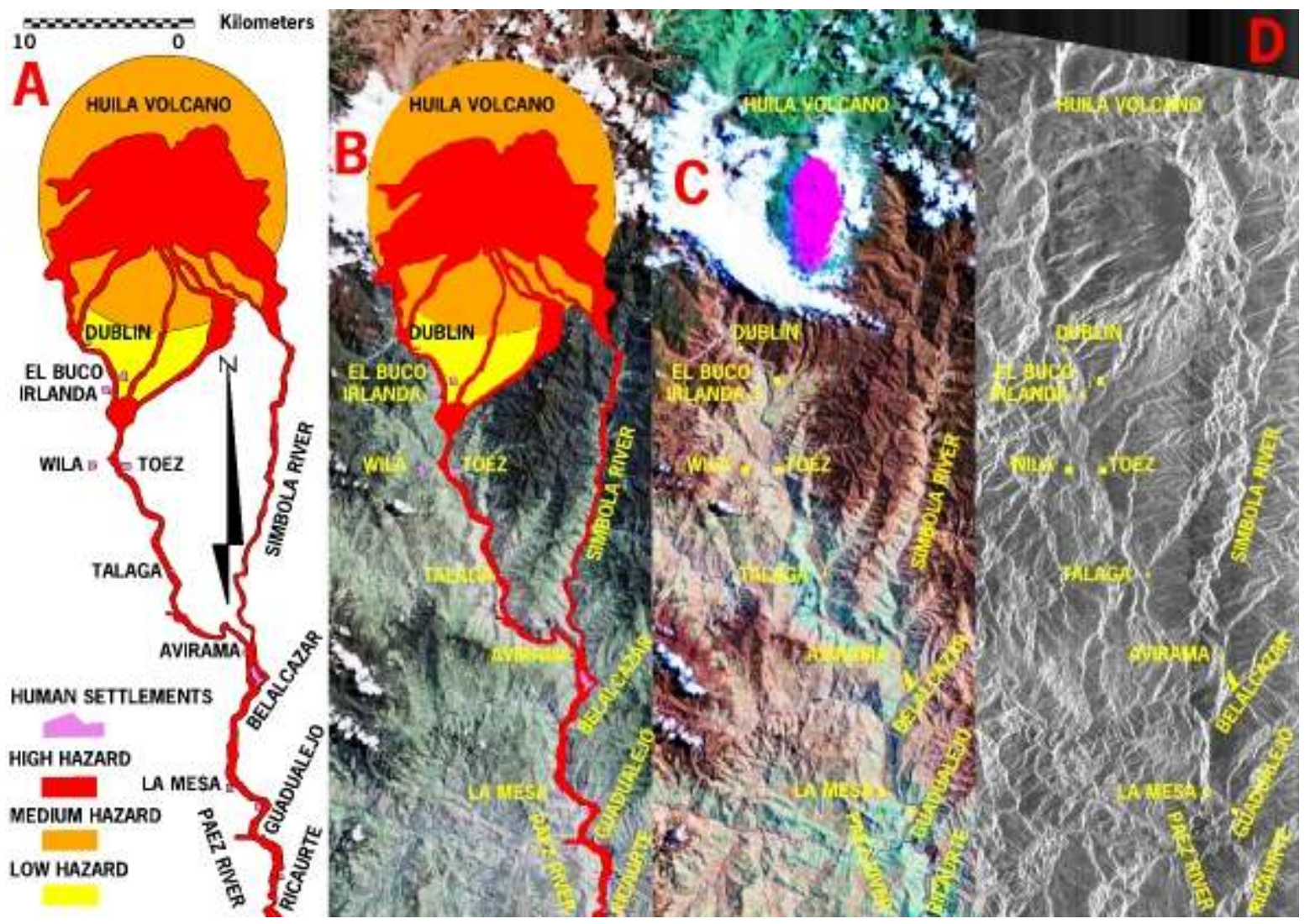

Figure 4. The volcanic hazard map of the Nevado del Huila volcano shows areas at risk in its surroundings (A). It was superimposed on a Landsat TM 5 color composite (3R-2G-1B) to create this mosaic (B), which is compared to Landsat TM 5 color composite 4R-5G-2B (C) and JERS data (D). (after INGEOMINAS, 2000). 
Figura 4. El mapa de amenaza volcánica del Volcán Nevado del Huila muestra áreas amenazadas en sus alrededores (A). Fue desplegado sobre una composición en falso color Landsat TM 5 (3R-2V-1 A) para crear este mosaico (B), que se compara con la composición en falso color 4R-5V-2 A (C), y datos del satélite JERS (D). (modificado de INGEOMINAS, 2000).

Often, volcanologists must assume the difficult role of explaining the uncertainties of volcanic hazards to a public unfamiliar with volcanoes. The process often leads to confusion, misunderstandings and strained relations between scientists and those responsible for the public welfare. To influence the decisions made by civil authorities during a volcanic crisis, volcanologists must establish more effective communication with elected officials, news media and local citizens (Peterson, 1988). Creating an effective visualization tool (volcanic hazard maps) is one way to accomplish it.

Even the most reliable volcanic hazard map is of little value unless it's presented in a meaningful format. Damaging consequences may follow scientific statements that are not fully understood or believed by civil leaders or the public (Wright \& Pierson, 1992). Using GIS, the entire spectrum of data covering different types of hazards in a given volcanic area could be displayed when needed. Volcanic hazard maps used in addition to remote sensing data and digital elevation models, seems to be the best way to help understand the decision makers any volcanic hazardous situation.

\section{3-D Visualization}

Remote sensing imagery offers many applications for hazard assessment of volcanic processes, if used along with ground-based information. A Landsat TM 5 subscene was taken from the scene that records the Nevado del Huila Volcano influence area. Two color composites were generated, one to help the local people visualize the landscape, and other for geological purposes. The first one was 3R-2G-1B (Fig. 4 B), because it emulates the human vision. The second one involves Landsat TM 5 bands which correspond with reflectance properties of vegetation, due to the vegetated nature of the considered area; the false color 
composite selected was 4R-5G-2B (Fig. 4 C). The Nevado del Huila Volcano hazard map polygons were superimposed to the first color composite, in order to enable querying attributes of image and vector data interactively in 3-D (Fig. 4 B). JERS data was used in addition to Landsat TM 5 images, because radar imagery can monitor volcanic eruptions at night (Fig. 4 D).

Every map uses elevation data and symbols to represent a 3-D world in a 2-D format. The third dimension (topography) happens to be the most difficult to perceive by the common people. A digital elevation model was created from the study area topographic map by averaging the elevations within the cells of a grid and generating a digital matrix of these elevations.

Digital maps offer more choices for relating hazard zones to the landscape, and several types prove especially effective in helping volcanologists communicate with the public. An effective method to improve a non-geologist's visualization and comprehension of any volcanic hazard map is to "drape" the different hazard zones as well as remote sensing images over a digital elevation model. 


\section{GEOAMBIENTE ON-LINE REVISTA ELETRÔNICA DO CURSO DE GEOGRAFIA DO CAMPUS AVANÇADO DE JATAÍ-GO Http://www.jatai.ufg.br/geo/geoambiente.htm [Jatai-GO] [n.1] [jul-dez/2003]
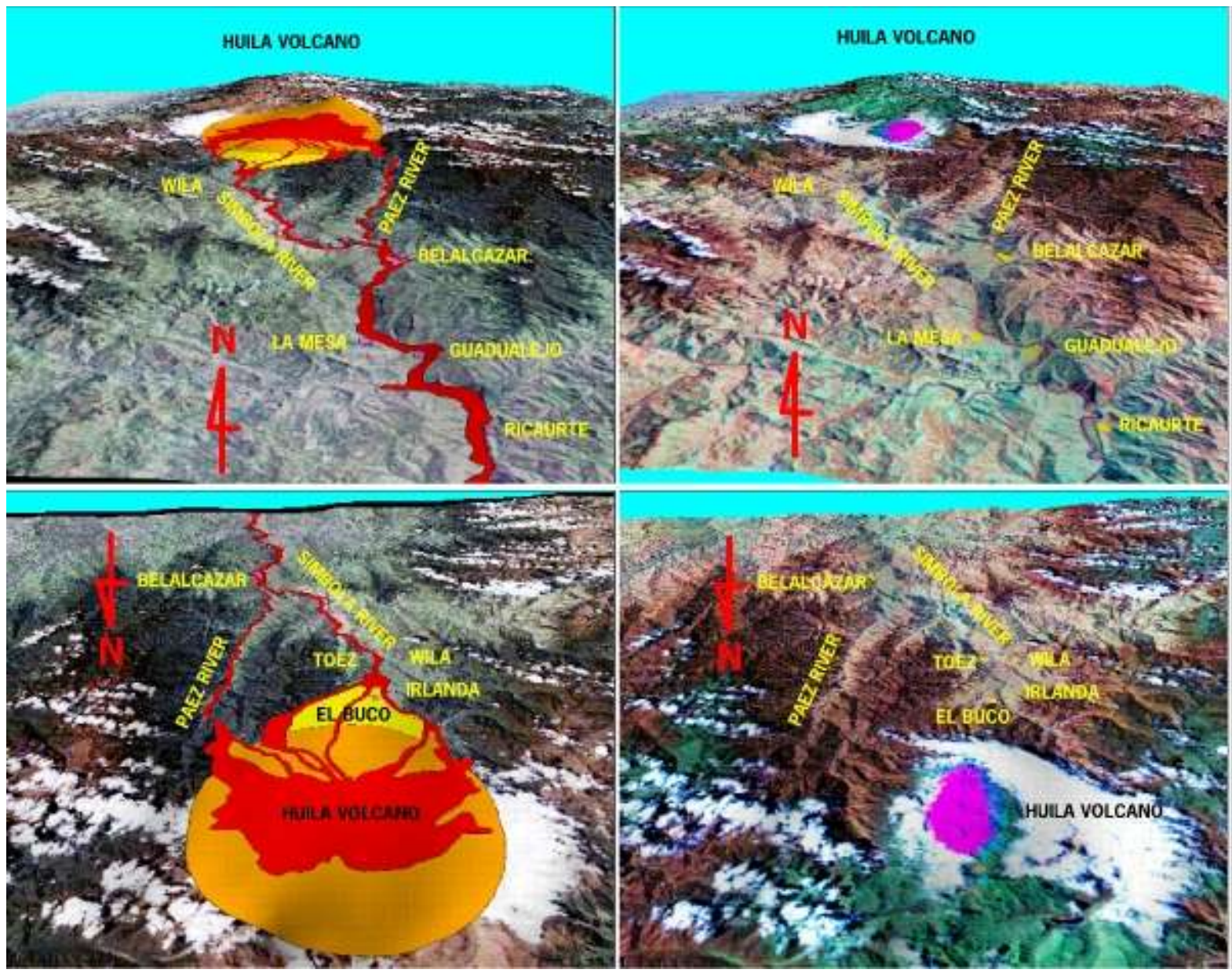

Figure 5. Perspective views of hazard zones and the surrounding landscape help public officials make better emergency management decisions and inform the public of specific volcanic hazards.

Figura 5. Las vistas en perspectiva de las zonas de amenaza y el paisaje circundante, ayudan a los oficiales del gobierno a tomar mejores decisiones para el manejo de la emergencia, $e$ informan al público en general sobre amenazas volcánicas específicas. 


\section{GEOAMBIENTE ON-LINE \\ REVISTA ELETRÔNICA DO CURSO DE GEOGRAFIA DO CAMPUS AVANÇADO DE JATAÍ-GO \\ Http://www.jatai.ufg.br/geo/geoambiente.htm \\ [Jatai-GO] [n.1] [jul-dez/2003]

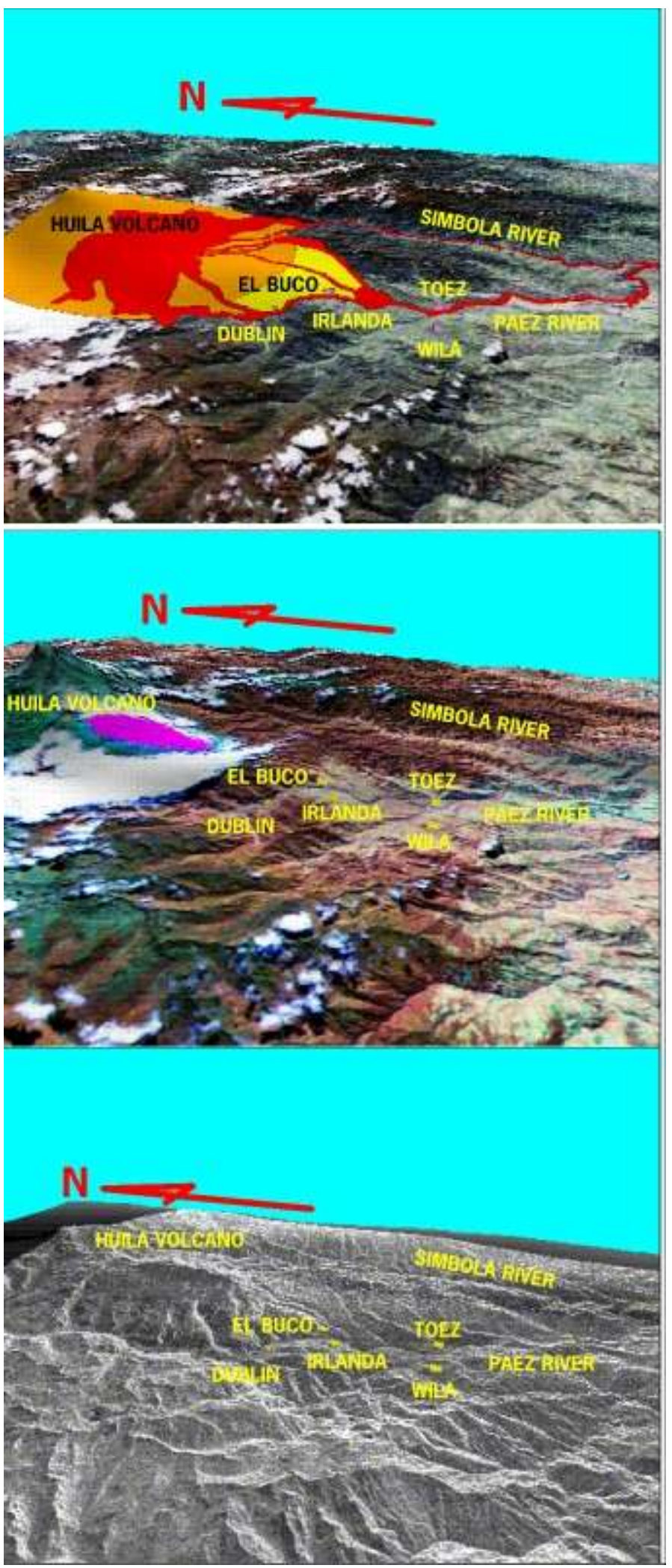


Figure 6. More perspective views of hazard zones (above), Landsat TM 5 color composite 4R$5 G-2 B$ (middle) and JERS data (below).

Figura 6. Más vistas en perspectiva de las zonas de amenaza (arriba), la composición en falso color Landsat TM 5 4R-5V-2 A (mitad) y los datos del satélito JERS (abajo).

\section{Perspective Views and scene visualization}

By draping different hazard zones and remote sensing images over digital elevation models (DEMs), scientists can create perspective views of hazard zones and simulated landscape (figures 5 and 6). In the past, generating these perspective views required painstaking, artistic renderings of topography and map polygons. Digital maps are easier to create, manipulate and modify. Working with any scene visualization software package available, enables to go beyond simple rendering in $3 \mathrm{D}$, because they support dynamic visualization, flight sequences, and the management/assimilation of multiple volcanic hazard data types in a real-time, 3D environment.

\section{Conclusions}

Volcanic hazard maps when used along with remote sensing data and digital elevation models are an effective tool to help volcanologists explain volcanic hazardous situations to those who are responsible for the public welfare and the community exposed to volcanic risk. The perspective views generated by this rendering in 3D methodology, allow the nonvolcanologist to see any volcanic hazard map as a 3-D representation of a 3-D world, where topography and its influence on volcanic hazard is evident.

GIS can be used as a communication technology to conduct lively continuing education programs, which effectively transfer information about volcanic hazards from scientists to people responsible for the public welfare and to public citizens exposed to volcanic hazard.

\section{References}




\section{GEOAMBIENTE ON-LINE}

REVISTA ELETRÔNICA DO CURSO DE GEOGRAFIA DO CAMPUS AVANÇADO DE JATAÍ-GO

INGEOMINAS, 2000. Atlas de Amenaza Volcanica en Colombia. 120p.

MARTINEZ, J.M., AVILA, G., AGUDELO, A., SCHUSTER, R.L., CASADEVALL, T.J. \& SCOTT, K.M., 1995. Landslides and Debris Flows triggered by the 6 June 1994 Paez Earthquake, Southwestern Colombia. Landslide News, 9: 13-15.

PETERSON, D.W., 1988. Volcanic Hazards and Public Response, Journal of Geophysical Research, Vol. 93, No. B5, 4161-4170.

PIERSON, T.C., JANDA, R.J., THOURET, J.C. \& BORRERO, C.A., 1990. Perturbation and melting of snow and ice by the 13 November 1985 eruption of Nevado del Ruiz, Colombia, and consequent mobilization, glow and deposition of lahars. Journal of Volcanology and Geothermal Research, 41: 17-66.

TILLING, R.I. \& LIPMAN, P.W., 1993. Lessons in Reducing Volcano Risk, Nature, 364: 277-280.

VOIGHT, B., 1990. The 1985 Nevado del Ruiz volcano catastrophe: anatomy and retrospection. Journal of Volcanology and Geothermal Research, 42: 151-188.

WRIGHT, T.L. \& PIERSON, T.C., 1992. Living with Volcanoes, U.S. Geological Survey, Circular 1073, 58p. 